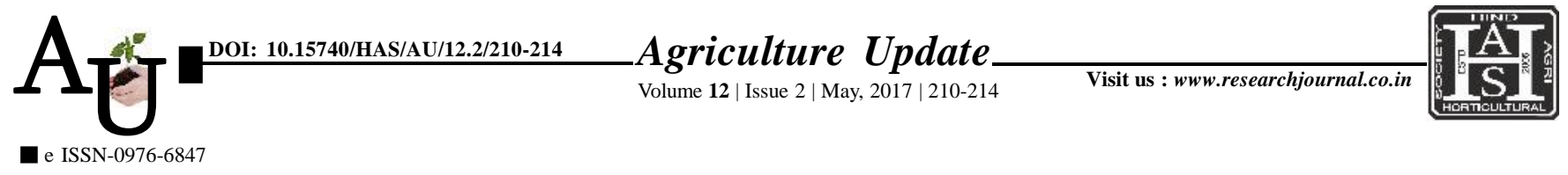

\title{
Research Автісle: Relationship between selected characteristics of tomato growers and their adoption level of recommended technology in Nashik district of Maharashtra state
}

Article Chronicle:
Received :
17.01.2017;
Revised :
05.03.2017;
Accepted:
15.03.2017

KeY Words :

Relationship, Adoption, Tomato growers
Author for correspondence :

\section{PARMESHWARI B. PAWAR} Department of Extension Education, K.K. Wagh College of Agriculture,

Saraswatinagar, NASHIK (M.S.) INDIA

Email:pb.pawar@kkwagh. edu.in; pari2805@ rediffmail.com

See end of the article for authors' affiliations

\section{S.M. HADOLE, PARMESHWARI B. PAWAR AND T.B. UGALE}

SUMMARY : The present research on relationship between socio-economic characteristics of tomato grower was conducted in Nashik district of Maharashtra state. Seventy tomato growers were selected randomly from ten villages. The data were collected by personal interview technique from tomato growers with the help of structured interview schedule. Mostly respondents were found in medium age category, higher secondary education, medium farming experience, joint and large family, medium level economic motivation, scientific orientation and risk orientation as well as medium knowledge level. The relationship of selected characteristics namely age, type of family, land holding, economic motivation and knowledge level were found to be positively and significantly correlated with overall adoption of recommended practices of tomato.

How to cite this article : Hadole, S.M., Pawar, Parmeshwari B. and Ugale, T.B. (2017). Relationship between selected characteristics of tomato growers and their adoption level of recommended technology in Nashik district of Maharashtra state. Agric. Update, 12(2): 210-214; DOI : 10.15740/HAS/AU/12.2/210-214. 